Article

\title{
Effectiveness of Dunaliella salina Extracts against Bacillus subtilis and Bacterial Plant Pathogens
}

\author{
Alfredo Ambrico ${ }^{1}$, Mario Trupo ${ }^{1}$ (D), Rosaria Magarelli ${ }^{1}$, Roberto Balducchi ${ }^{1}$, Angelo Ferraro ${ }^{2} \mathbb{D}$, \\ Evangelos Hristoforou ${ }^{2}{ }^{-1}$, Tiziana Marino ${ }^{3}$, Dino Musmarra ${ }^{3}{ }^{\mathbb{D}}$, Patrizia Casella ${ }^{4}$ and \\ Antonio Molino 4,*(D) \\ 1 Energy and Sustainable Economic Development Department of Sustainability, ENEA Italian National \\ Agency for New Technologies, R.C. Trisaia S.S. 106 Jonica, 75026 Rotondella, Italy; \\ alfredo.ambrico@enea.it (A.A.); mario.trupo@enea.it (M.T.); rosaria.magarelli@enea.it (R.M.); \\ roberto.balducchi@enea.it (R.B.) \\ 2 School of Electrical and Computer Engineering, National Technical University of Athens, Zografou Campus, \\ 9, IroonPolytechnioustr, 15780 Athens, Greece; ferraro@eie.gr (A.F.); hristoforou@ece.ntua.gr (E.H.) \\ 3 Department of Civil and Building Engineering, Design and Environment, Università degli Studi della \\ Campania "L.Vanvitelli”, Real Casa dell'Annunziata, Via Roma 9, 81031 Aversa, Italy; \\ tiziana.marino@unicampania.it (T.M.); dino.musmarra@unicampania.it (D.M.) \\ 4 Energy and Sustainable Economic Development Department of Sustainability, ENEA Italian National \\ Agency for New Technologies, R.C. Portici, Piazzale Enrico Fermi 1, 80055 Portici, Italy; \\ patrizia.casella@enea.it \\ * Correspondence: antonio.molino@enea.it; Tel.: +39-081-772-3276
}

Received: 18 May 2020; Accepted: 24 July 2020; Published: 28 July 2020

check for updates

\begin{abstract}
Several bacteria pathogens are responsible for plant diseases causing significant economic losses. The antibacterial activity of Dunaliella salina microalgae extracts were investigated in vitro and in vivo. First, biomass composition was chemically characterized and subjected to extraction using polar/non-polar solvents. The highest extraction yield was obtained using chloroform:methanol $(1: 1 \mathrm{v} / \mathrm{v})$ equal to $170 \mathrm{mg} \mathrm{g}^{-1}$ followed by ethanol $\left(88 \mathrm{mg} \mathrm{g}^{-1}\right)$ and hexane $\left(61 \mathrm{mg} \mathrm{g}^{-1}\right)$. In vitro examination of hexane extracts of Dunaliella salina demonstrated antibacterial activity against all tested bacteria. The hexane extract showed the highest amount of $\beta$-carotene with respect to the others, so it was selected for subsequent analyses. In vivo studies were also carried out using hexane extracts of $D$. salina against Pseudomonas syringae pv. tomato and Pectobacterium carotovorum subsp. carotovorum on young tomato plants and fruits of tomato and zucchini, respectively. The treated young tomato plants exhibited a reduction of $65.7 \%$ incidence and $77.0 \%$ severity of bacterial speck spot disease. Similarly, a reduction of soft rot symptoms was observed in treated tomato and zucchini fruits with a disease incidence of $5.3 \%$ and $12.6 \%$ with respect to $90.6 \%$ and $100 \%$, respectively, for the positive control.
\end{abstract}

Keywords: microalgae; antibacterial activity; algal bioactive compounds; D. salina; microalgae extracts; $\beta$-carotene; bacterial speck spot disease

\section{Introduction}

Bacteria can have important functional roles in agriculture, for example, in interactions with soil, roots, and microorganisms, they can bring beneficial effects for the health and growth of plants; but, on the other hand, pathogenic bacteria can cause serious plant diseases.

Several Gram-negative and Gram-positive bacterial pathogens are responsible for plant diseases causing significant economic losses in crop production [1,2]. The pathogenic bacteria can be spread several ways including by rain, wind, birds, or insects [3,4]. In addition, a pathogen's incidence may 
be favored by the propagation of plants with bacteria-infected material or by pruning infected trees [5]. Bacterial infections occur at any time during pre- and post-harvest processes reducing the quantity and quality of fruits and vegetables [6,7]. Gram-negative bacteria, such as Pseudomonas syringae and Pectobacterium carotovorum, are important bacteria in scientific and economic terms and can cause very substantial production losses and improper storage [8,9].

These pathogens typically enter the host through wound sites or natural openings, such as lenticels, and remain latent in intracellular spaces and vascular tissue [10-12]. Some environmental factors, such as temperature, low oxygen concentration, and free water, can affect disease progress. During favorable environmental conditions, bacterial pathogens produce a cellulolytic multi-enzyme complex that cause plant cell lysis and tissue collapse [13]. Nowadays, recent European restrictions on the use of chemicals and antibiotics for the management of bacterial diseases in agriculture have been enacted [14]. Copper-based treatments, despite being non-environmentally friendly and having a negative impact on microorganisms in soil, phyllosphere, and rhizosphere, are principally adopted to control bacterial plant diseases $[15,16]$, while host resistance and appropriate agronomic practices, such as seeds certification, irrigation, and fertilization, are the principal strategies for integrated control of bacterial diseases in fields. During post-harvest, the more effective solutions to prevent bacterial diseases are proper storage conditions and good handling practices such as cleaning and disinfestations of equipment [17]. Therefore, alternative solutions are becoming essential to preserve the freshness and quality of food products. Natural compounds derived from microalgae can be exploited for these objectives due to the fact of their promising antibacterial properties [18,19].

Microalgae are aquatic photosynthetic organisms, converting $\mathrm{CO}_{2}$ and light into valuable, energy-rich organic compounds. In aquatic environments, prokaryotic and eukaryotic microalgae are annually responsible for about 50\% of carbon fixation [20]. Microalgae are cultivated in photo-bioreactors or open systems for different final applications and purposes such as human consumption. Microalgae are indeed a source of high value healthy compounds like carotenoids and polyunsaturated fatty acids [21,22] whose systematic examination began in the 1950s [23,24]. At the same time, early in vivo observations about the pharmaceutical properties of microalgae strains were conducted in 1970 at the Roche Research Institute of Marine Pharmacology in Australia [25]. Recently, several studies have focused on evaluating in vitro and in vivo antimicrobial proprieties of algae [22,25] and microalgae extracts [19], such as Botryococcus braunii [21] and Scenedesmus sp. [18], that can produce different compound-shaving antibiotic, antioxidant, and antimicrobial properties that can potentially damage pathogenic cells. Therefore, novel natural antimicrobial molecules derived from microalgae can be investigated for crop protection [26,27]. From these natural antimicrobial substances, carotenoids are showing very promising results [28,29].

According to our knowledge, Dunaliella salina (a unicellular, biflagellate, naked green alga) represents an important source of $\beta$-carotene which has been investigated for its antimicrobial proprieties [30-33]. The aim of the present study was to evaluate the antibacterial proprieties of D. salina extracts.

The antibacterial effects of $D$. salina extracts were evaluated via in vitro and in vivo experimental trials. The antibacterial activity of $D$. salina extracts were compared with that of the $\beta$-carotene chemical standard.

\section{Results}

\subsection{Extraction Yield and Characterization Pre-and Post-Extraction}

Dunaliella salina chemical composition was characterized in terms of humidity, ash that amounted to $6.63 \%$ ( $w / w$ on wet sample), and $48.74 \%$ ( $w / w$ on wet sample) as reported in Table 1 . Carbohydrates were the main constituent with a percentage equal to $25.31 \%$ ( $w / w$ on dry basis). Proteins and total dietary fiber (TDFs) were equal to $10.03 \%$ ( $w / w$ on dry basis) and $8.97 \%$ ( $w / w$ on dry basis). Carotenoids amounted to $3.46 \%$ and lipids were equal to $3.49 \%$ ( $w / w$ on dry basis). Fatty acids methyl esters 
(FAMEs) composition was investigated and saturated fatty acids (SFAs) and polyunsaturated fatty acids (PUFAs) were the most abundant: $1532.68 \mathrm{mg} 100 \mathrm{~g}^{-1}$ on a dry basis and $1055.97 \mathrm{mg} 100 \mathrm{~g}^{-1}$ on a dry basis, respectively (Table 1 ).

Table 1. Chemical composition of Dunaliella salina and fatty acids composition.

\begin{tabular}{|c|c|}
\hline \multicolumn{2}{|c|}{ Chemical-Physical Features } \\
\hline Humidity * & $6.63 \pm 0.25$ \\
\hline Ash ${ }^{\#}$ & $48.74 \pm 2.50$ \\
\hline Proteins \# & $10.03 \pm 0.57$ \\
\hline Carbohydrates \# & $25.31 \pm 1.55$ \\
\hline Lipids \# & $3.49 \pm 0.10$ \\
\hline Total Dietary Fibers \# & $8.97 \pm 0.50$ \\
\hline Carotenoids \# & $3.46 \pm 0.15$ \\
\hline \multicolumn{2}{|c|}{ Fatty acids methyl esters composition (mg $100 \mathrm{~g}^{-1}$ on dry basis) } \\
\hline \multicolumn{2}{|c|}{ SFAs $\S$} \\
\hline Tridecanoic acid & $<\mathrm{Ldl}$ \\
\hline Palmitic acid & $965.00 \pm 1.15$ \\
\hline Pentadecanoic acid & $<\mathrm{Ldl}$ \\
\hline Heptadecanoic acid & $<\mathrm{Ldl}$ \\
\hline Stearic acid & $567.68 \pm 0.56$ \\
\hline Arachidic acid & $<$ Ldl \\
\hline$\sum$ SFAs & $1532.68 \pm 1.70$ \\
\hline \multicolumn{2}{|l|}{ MUFAs $\S$} \\
\hline Palmitoleic acid & $<\mathrm{Ldl}$ \\
\hline cis-9-Octadecenoic acid (oleic acid) & $567.56 \pm 1.29$ \\
\hline Myristoleic acid & $<\mathrm{Ldl}$ \\
\hline Nervonic acid & $<\mathrm{Ldl}$ \\
\hline Erucic acid & $<\mathrm{Ldl}$ \\
\hline$\sum$ MUFAs & $567.56 \pm 1.29$ \\
\hline \multicolumn{2}{|l|}{ PUFAs $\$$} \\
\hline cis-8,11,14-Eicosatrienoic acid & $<\mathrm{Ldl}$ \\
\hline Linoelaidic acid & $<\mathrm{Ldl}$ \\
\hline Linoleic acid & $519.75 \pm 0.63$ \\
\hline$\gamma$-Linolenic acid & $536.22 \pm 0.12$ \\
\hline Arachidonic acid & $<\mathrm{Ldl}$ \\
\hline cis-5,8,11,14,17-Eicosapentaenoic acid & $<$ Ldl \\
\hline$\sum$ PUFAs & $1055.97 \pm 0.75$ \\
\hline
\end{tabular}

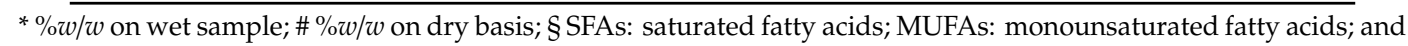
PUFAs: polyunsaturated fatty acids. All data are the mean value \pm standard deviation. Ldl $=$ lower detection limit.

Dunaliella salina dry biomass was extracted using solvents with different polarity. Ethanol was chosen since this is a Generally Recognized As Safe (GRAS) solvent, directly usable in food and pharmaceutical industries and allowed to obtain an extraction yield comparatively lower than that of chloroform:methanol (1:1) mixture but higher than that obtained with hexane (Figure 1). The solvent polarity is an important factor in estimating affinity of compounds with similar polarity. The extraction yield of $D$. salina biomass using chloroform:methanol $\left(170 \mathrm{mg} \mathrm{g}^{-1}\right)$ was two- and three-fold higher in respect to those obtained with ethanol $\left(88 \mathrm{mg} \mathrm{g}^{-1}\right)$ and hexane $\left(61 \mathrm{mg} \mathrm{g}^{-1}\right)$ (Figure 1). 


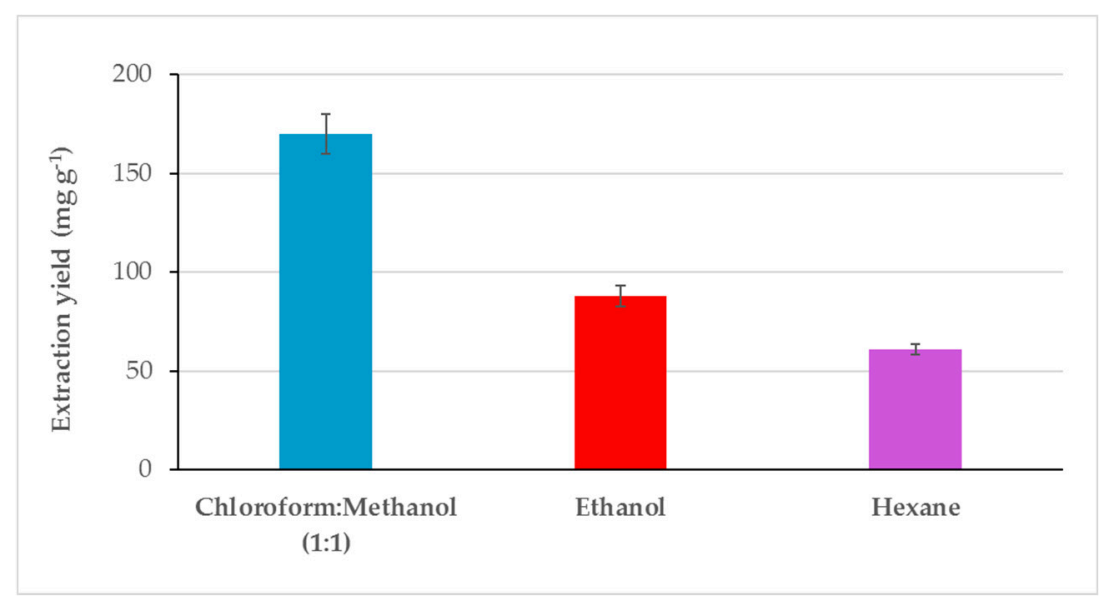

Figure 1. Extraction yield obtained by using solvents with different polarity.

For each extraction test, the chemical composition of $D$. salina extracts were evaluated as shown in Table 2. Hexane extract $D$. salina showed the highest content of carotenoids (36.6\%) in respect to ethanol $(12.8 \%)$ and chloroform:methanol (1:1 v/v) (16.4\%) extracts. The $B$-carotene amount was $98 \%$ of the total carotenoids in the hexane extract. The chloroform:methanol (1:1) extract of $D$. salina contained the highest protein content $(60.6 \%)$, while the ethanol extract contained the highest lipids content $(18.8 \%)$.

Table 2. Chemical characterization of $D$. salina extracts using solvents with different polarity.

\begin{tabular}{cccc}
\hline Compounds & Chloroform:Methanol (1:1) & Ethanol & Hexane \\
\hline Ash & $30.3 \%$ & $32.5 \%$ & $36.2 \%$ \\
Protein & $26.4 \%$ & $24.8 \%$ & $14.1 \%$ \\
Carbohydrates & $3.0 \%$ & $2.6 \%$ & $1.4 \%$ \\
TDF & $9.1 \%$ & $8.5 \%$ & $5.6 \%$ \\
Carotenoids & $16.4 \%$ & $12.8 \%$ & $36.6 \%$ \\
of which: & & & \\
Beta-carotene & $85.0 \%$ & $90.0 \%$ & $98.0 \%$ \\
Lutein & $15.0 \%$ & $10.0 \%$ & $2.0 \%$ \\
Lipids & $14.8 \%$ & $18.8 \%$ & $6.1 \%$ \\
of which FAMEs: & $90.1 \%$ & $85.3 \%$ & $90.0 \%$ \\
FAMEs composition: & & & \\
SFAs & $30.1 \%$ & $35.0 \%$ & $32.0 \%$ \\
MUFAs & $60.1 \%$ & $56.7 \%$ & $65.9 \%$ \\
PUFAs & $9.8 \%$ & $8.3 \%$ & $2.1 \%$ \\
\hline
\end{tabular}

\subsection{In Vitro Antimicrobial Activity of Different Extracts of Microalgae}

\subsubsection{Disc Diffusion Method}

The antibacterial properties of $D$. salina extracts were screened by the disc diffusion method (Table 3). All extracts of $D$. salina displayed an antibacterial activity against all tested bacteria. Specifically, hexane extracts of $D$. salina at the concentration of $97.0 \mathrm{mg} \mathrm{mL}^{-1}$ showed a higher inhibition zone equal to $20 \mathrm{~mm}$ against $B$. subtilis (BS), while the inhibition zones against $P$. carotovorum subsp. carotovorum (PCC) and P. syringae pv. tomato (PST) amounted to 9 and $12 \mathrm{~mm}$, respectively. Ethanolic extracts at the concentration of $214.0 \mathrm{mg} \mathrm{mL}^{-1}$ showed inhibition zones of $21 \mathrm{~mm}$ against the BS strain, $11 \mathrm{~mm}$ against the PCC strain, and $9 \mathrm{~mm}$ against the PST strain. The chloroform-methanol extract was used at the concentration of $350 \mathrm{mg} \mathrm{mL}^{-1}$, and the obtained inhibition zone was 10, 8, and $13 \mathrm{~mm}$ against $P$. carotovorum subsp. carotovorum, P. syringae pv. tomato, and B. subtilis, respectively. The ciprofloxacin antibiotic was tested at $0.15 \mathrm{mg} \mathrm{mL}^{-1}$ showing an inhibition zone $32 \mathrm{~mm}$ against the BS strain, $24 \mathrm{~mm}$ against the PST strain, and $20 \mathrm{~mm}$ against the PCC strain. 
Table 3. Antibacterial activity of $D$. salina extracts by disc diffusion method.

\begin{tabular}{ccccc}
\hline \multirow{2}{*}{ Samples } & $\begin{array}{c}\text { Concentration } \\
\left(\mathbf{m g ~ m L}^{-1}\right)\end{array}$ & $\begin{array}{c}\text { P. carotovorum subsp. } \\
\text { carotovorum } \text { DSM30168 }\end{array}$ & $\begin{array}{c}\text { P. syringae pv. } \\
\text { tomato EPS3 }\end{array}$ & B. subtilis ET-1 \\
\hline Chloroform:Methanol extract & 350.0 & $10.0 \pm 0.1$ & $8.0 \pm 0.1$ & $13.0 \pm 0.1$ \\
Ethanol extract & 214.0 & $11.0 \pm 0.1$ & $9.0 \pm 0.1$ & $21.0 \pm 0.2$ \\
Hexane extract & 97.0 & $9.0 \pm 0.1$ & $12.0 \pm 0.1$ & $20.0 \pm 0.2$ \\
Ciprofloxacin & 0.15 & $20.0 \pm 0.2$ & $24.0 \pm 0.2$ & $32.0 \pm 0.3$ \\
\hline
\end{tabular}

\subsubsection{Minimum Inhibitory Concentration}

For the determination of the minimum inhibitory concentration (MIC) values, D. salina extracts were subjected to the broth dilution method. After incubation time, when in control tubes, the microbial biomass was well grown, the inhibitory activity of $D$. salina extracts were evaluated. The results in Table 4 showed that for hexane extracts of D. salina, the MIC was achieved at $3.0 \mathrm{mg} \mathrm{mL}^{-1}$ and only against $B$. subtilis at $0.3 \mathrm{mg} \mathrm{mL}^{-1}$. Chloroform:methanol extracts were active only against $B$. subtilis with an MIC value of $3.0 \mathrm{mg} \mathrm{mL}^{-1}$, while ethanolic extracts of $D$. salina inhibited the growth of $P$. syringae and B. subtilis at a concentration of $3.0 \mathrm{mg} \mathrm{mL}^{-1}$.

Table 4. Minimum inhibitory concentration (MIC) of D. salina extract against P. carotovorum, P. syringae, and B. subtilis.

\begin{tabular}{cccc}
\hline & \multicolumn{3}{c}{ MIC Value $\left(\mathbf{m g ~ m L}^{-\mathbf{1}}\right)$} \\
\cline { 2 - 4 } & P. carotovorum & P. syringae & B. subtilis \\
\hline Chloroform:Methanol & $>3.0$ & $>3.0$ & 3.0 \\
Ethanol & $>3.0$ & $>3.0$ & 3.0 \\
\hline Hexane & 3.0 & 3.0 & 0.3 \\
\hline
\end{tabular}

\subsection{Effect of D. salina Extracts on Disease Development in In Vivo Conditions}

\subsubsection{Application of D. salina Extracts to Control Bacterial Speck Spot Caused by P. syringae}

Dark-brown spots surrounded by a chlorotic halo appeared 5 days after inoculation with DI and DS of $3.2 \%$ and $0.82 \%$, respectively. A final DI and DS of $37.9 \%$ and $2.2 \%$ were observed. A similar DI and DS not statistically different from those of positive control were recorded. A significant reduction of disease symptoms was observed on leaves of tomato plants treated with $D$. salina hexane at a concentration of $10 \mathrm{mg} \mathrm{mL}^{-1}$. In particular, a DI of $0 \%, 7.2 \%$, and $13.2 \%$ after 5,10 , and 15 days were recorded, respectively. At the same time, the DS was $0 \%, 0.02 \%$, and $0.505 \%$, respectively. No negative (phytotoxic) effects were recorded on tomato plants of the healthy control (Table 5, Figures 2 and 3).

Table 5. Disease incidence (DI) and disease severity (DS) of bacterial specks on inoculated tomato plants at 5,10 , and 15 days post-inoculation.

\begin{tabular}{|c|c|c|c|c|c|c|}
\hline \multirow{2}{*}{ Treatments } & \multicolumn{2}{|c|}{5} & \multicolumn{2}{|c|}{10} & \multicolumn{2}{|c|}{15} \\
\hline & DI (\%) & DS (\%) & DI (\%) & DS (\%) & DI (\%) & DS (\%) \\
\hline Positive Control & $3.2 \pm 0.1^{b^{*}}$ & $0.82 \pm 0.3^{b}$ & $25.2 \pm 0.1^{b}$ & $1.8 \pm 0.3^{b}$ & $37.9 \pm 0.2^{b}$ & $2.2 \pm 0.1^{b}$ \\
\hline Solvent Control & $3.5 \pm 0.1^{b}$ & $0.93 \pm 0.2^{b}$ & $24.2 \pm 0.1^{b}$ & $1.85 \pm 0.1^{b}$ & $36.7 \pm 0.9^{b}$ & $2.9 \pm 0.2^{b}$ \\
\hline Hexane extract & $0.0^{\mathrm{a}}$ & $0.0^{\mathrm{a}}$ & $7.2 \pm 0.5^{\mathrm{a}}$ & $0.02 \pm 0.1^{\mathrm{a}}$ & $13.2 \pm 0.4^{\mathrm{a}}$ & $0.505 \pm 0.1^{a}$ \\
\hline
\end{tabular}

* Data are shown as the means \pm standard deviation. Within each column, mean values followed by the same letter

$(a, b)$ are not significantly different according to Tukey's test $(\alpha=0.05)$. 

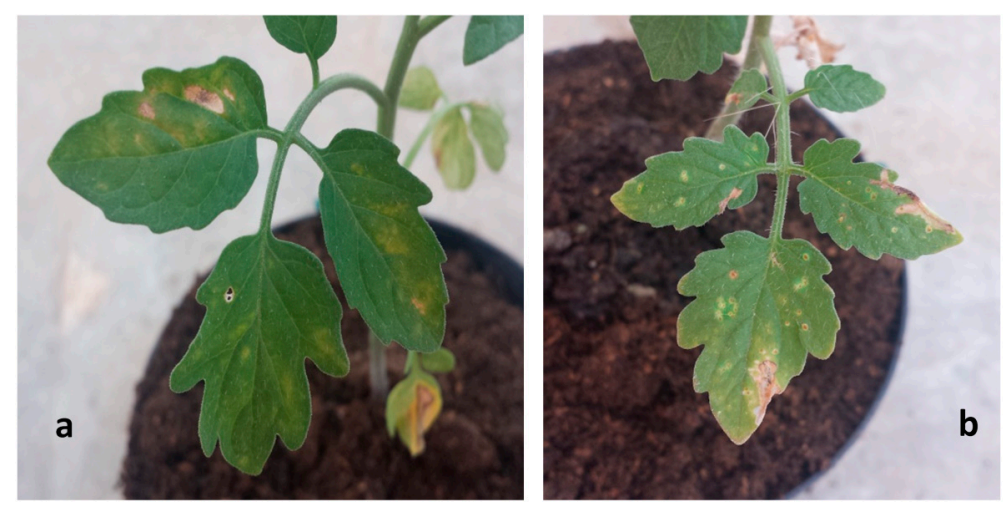

Figure 2. Symptoms of bacterial speck disease on inoculated tomato leaves after 10 (a) and 15 (b) days post-inoculation.

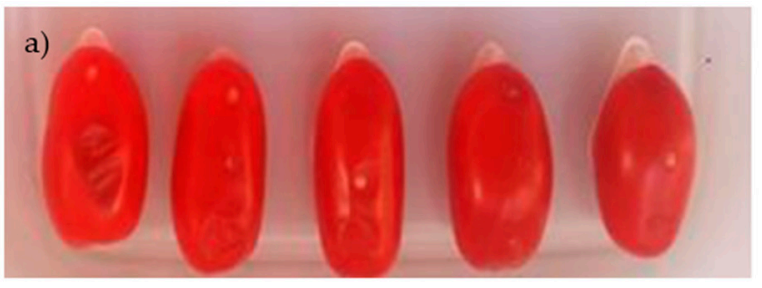

Positive control

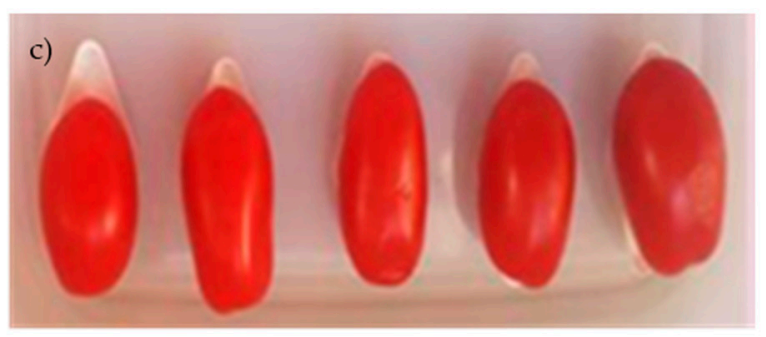

Dunaliella salina extract $5 \mathrm{~g} \mathrm{~L}^{-1}$

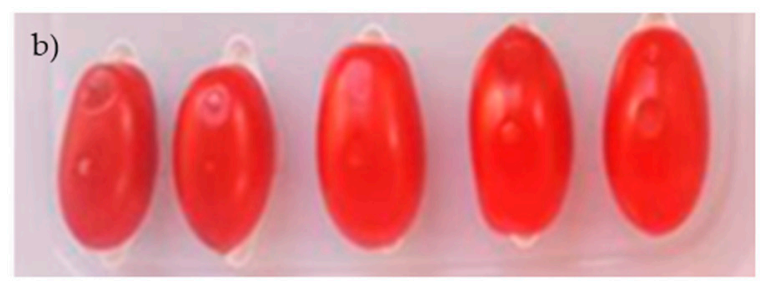

Solvent control

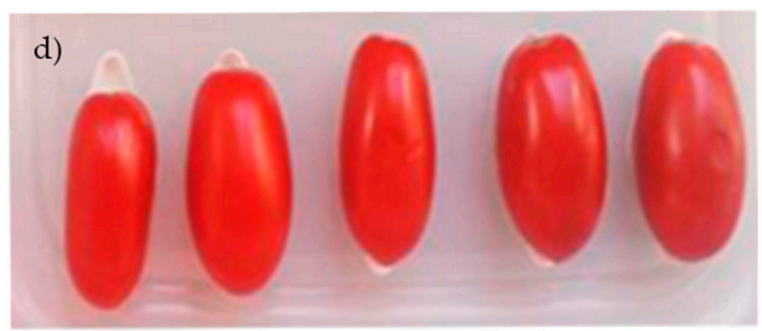

Dunaliella salina extract $10 \mathrm{~g} \mathrm{~L}^{-1}$

Figure 3. Effect of D. salina extracts against P. carotovorum subsp. carotovorum on tomato fruits: (a) positive control, (b) solvent control, (c) Dunaliella salina extract $5 \mathrm{~g} \mathrm{~L}^{-1}$, (d) Dunaliella salina extract $10 \mathrm{~g} \mathrm{~L}^{-1}$.

2.3.2. Application of D. salina Extracts to Control Bacterial Soft Rot Caused by P. carotovorum subsp. carotovorum on Tomatoes and Zucchini Fruits

Antibacterial activity of hexane $D$. salina extracts against $P$. carotovorum subsp. carotovorum (PCC) was investigated in vivo. The results in Table 6 show a strong reduction of soft rot symptoms on tomato and zucchini fruits artificially inoculated with the PCC strain and treated with D. salina extracts at two different concentrations 10 and $5 \mathrm{mg} \mathrm{mL}^{-1}$. In the positive control, tomatoes showed the typical small water-soaked lesion on the inoculation point (Figure 3). Disease incidence was detected equal to 33.4\% (Table 6). Tomatoes inoculated with P. carotovorum subsp. carotovorum and treated with D. salina extracts at concentrations of 10 and $5 \mathrm{mg} \mathrm{mL}^{-1}$ did not show infected wounds. In the positive control, the number of infected wounds increased, reaching a disease incidence of $80.6 \%$, while a significant antibacterial effect was achieved on tomatoes treated with $D$. salina extracts at concentrations of 10 and $5 \mathrm{mg} \mathrm{mL}^{-1}$, measuring a disease incidence of $5.3 \%$ and $12.7 \%$, respectively. In solvent control, a disease incidence was recorded equal to $27.7 \%$ and $77.9 \%$ at 48 and $96 \mathrm{~h}$, respectively. Disease incidence (DI) were not statistically different from those observed on the positive control. 
Table 6. Disease incidence (DI) on tomato and zucchini fruits after 48 and $96 \mathrm{~h}$ from inoculation.

\begin{tabular}{|c|c|c|c|c|}
\hline \multirow[t]{2}{*}{ Treatments } & \multicolumn{4}{|c|}{ Disease Incidence (\%) } \\
\hline & \multicolumn{2}{|c|}{ Tomatoes Fruits } & \multicolumn{2}{|c|}{ Zucchini Fruits } \\
\hline & \multicolumn{4}{|c|}{ Incubation Time (hours) } \\
\hline & 48 & 96 & 48 & 96 \\
\hline Positive control & $33.4 \pm 0.32^{\mathrm{a}^{*}}$ & $80.6 \pm 0.56^{b}$ & $90.4 \pm 0.33^{a}$ & $100.0^{\mathrm{b}}$ \\
\hline Solvent control & $27.7 \pm 0.32^{\mathrm{a}}$ & $77.9 \pm 0.43^{b}$ & $86.2 \pm 0.23^{a}$ & $100.0^{\mathrm{b}}$ \\
\hline Extract $10 \mathrm{mg} \mathrm{mL}^{-1}$ & $0.0 c \pm 0.0$ & $5.3 \pm 0.23^{c}$ & $0.0 c \pm 0.0$ & $12.6 \pm 0.15^{\mathrm{c}}$ \\
\hline Extract $5 \mathrm{mg} \mathrm{mL}^{-1}$ & $0.0 c \pm 0.0$ & $12.7 \pm 0.12^{a}$ & $0.0 \mathrm{c} \pm 0.0$ & $26.1 \pm 0.22^{\mathrm{a}}$ \\
\hline
\end{tabular}

* Data are shown as the means \pm standard deviation. Within each column, mean values followed by the same letter

$(a, b, c)$ are not significantly different according to Tukey's test $(\alpha=0.05)$.

The microalgae extract treatments also resulted in effective control of bacterial soft rot on zucchini inoculated with P. carotovorum subsp. carotovorum. A significant disease incidence was observed at $96 \mathrm{~h}$ at $12.6 \%$ and $26.1 \%$ in zucchini fruits treated using D. salina extracts at the concentrations of 10 and $5 \mathrm{mg} \mathrm{mL}^{-1}$, respectively. No significant differences in the percentages of infected wounds were observed between the solvent and the positive controls for all fruits which were completely rotten at the end of the experiments (Table 6). For both trials, the healthy control did not show any symptoms after $96 \mathrm{~h}$ from inoculation.

\subsection{Relationship between $\beta$-carotene Concentration and Antibacterial Activity}

The results of the values of the inhibition zones for $D$. salina extracts and $\beta$-carotene against P. carotovorum subsp. carotovorum, P. syringae pv. tomato and B. subtilis are shown in Table 7 . The $\beta$-carotene sample at a concentration of $10 \mathrm{mg} \mathrm{mL}^{-1}$ showed high antimicrobial activity against all tested bacteria. Indeed, an inhibition zone of $9.8,10.5$, and $18.1 \mathrm{~mm}$ was measured for P. carotovorum subsp. carotovorum, P. syringae pv. tomato, and B. subtilis, respectively. These value of inhibition zones were not significantly different from those produced by samples of a $D$. salina hexane extract at a concentration of $100 \mathrm{mg} \mathrm{mL}^{-1}$.

Table 7. Antibacterial activity of $D$. salina extracts at a concentration of $100 \mathrm{mg} \mathrm{mL}^{-1}$ and $\beta$-carotene (chemical standard) at concentrations of 10,5 , and $3 \mathrm{mg} \mathrm{mL}^{-1}$.

\begin{tabular}{|c|c|c|c|c|c|}
\hline \multirow[b]{2}{*}{ Sample } & \multirow[b]{2}{*}{$\begin{array}{c}\text { Sample } \\
\text { Concentration } \\
\left(\mathrm{mg} \mathrm{mL}^{-1}\right)\end{array}$} & \multirow[b]{2}{*}{$\begin{array}{l}\beta \text {-carotene } \\
\text { Concentration } \\
\left(\mathrm{mg} \mathrm{mL}^{-1}\right)\end{array}$} & \multicolumn{3}{|c|}{ Inhibition Zone (mm) } \\
\hline & & & $\begin{array}{l}\text { P. carotovorum } \\
\text { subsp. } \\
\text { carotovorum }\end{array}$ & P. syringae pv. & B. subtilis \\
\hline$\beta$-carotene SD & & 10 & $9.8 \pm 0.5^{\mathrm{a}^{*}}$ & $10.5 \pm 0.4^{\mathrm{a}}$ & $18.1 \pm 0.2^{a}$ \\
\hline$\beta$-carotene SD & & 5 & $5.1 \pm 0.3^{b}$ & $8.4 \pm 0.3^{b}$ & $9.3 \pm 0.2^{c}$ \\
\hline Chloroform:Methanol extract & 100 & 13.9 & $6.2 \pm 0.2^{b}$ & $7.7 \pm 0.3^{b}$ & $9.1 \pm 0.6^{c}$ \\
\hline Hexane extract & 100 & 35.9 & $10.5 \pm 0.8^{a}$ & $11.2 \pm 0.7^{\mathrm{a}}$ & $19.7 \pm 0.2^{\mathrm{a}}$ \\
\hline Ethanol extract & 100 & 11.5 & $7.2 \pm 0.2^{b}$ & $6.4 \pm 0.4^{\mathrm{c}}$ & $14.2 \pm 0.8^{b}$ \\
\hline
\end{tabular}

${ }^{*}$ Data are shown as the means \pm standard error. In column, the means followed by a different letter $(a, b, c)$ are significantly different according to the Tukey's HSD test $(\alpha=0.05)$.

\section{Discussion}

The control of crop diseases by eco-friendly means and products is among the major priorities for the agricultural and food industries. Pathogenic bacteria are able to infect hosts causing severe diseases to many agricultural crops. The discovery of new natural compounds able to prevent and manage bacterial plant diseases is a crucial step in agriculture research. In this context, in this study, D. salina biomass was subjected to solvent extraction by a Dionex ASE 200 extractor with the aim to check extracts' antibacterial proprieties. The results clearly indicate a significant antibacterial activity with a different inhibition level of each $D$. salina extract. Among the extracts, those obtained using 
hexane exhibited a better antibacterial effect although the worst extraction yield performance was detected in the same.

In particular, the hexane-based extracts of $D$. salina showed a MIC value of $0.3 \mathrm{mg} \mathrm{mL}^{-1}$ for B. subtilis and $3.0 \mathrm{mg} \mathrm{mL}^{-1}$ for P. carotovorum subsp. carotovorum and P. syringae. The observed difference in microbial sensitivities to the microalgae extracts may be attributed to the fact that cell walls in Gram-positive bacteria consist of a single layer, whereas Gram-negative bacterial cell walls are a multilayered structure bounded by an impermeable outer phospholipid membrane which is an effective barrier against hydrophobic substances [34,35]. Similar MIC values for $D$. salina extracts were recently reported in other independent studies carried out by Jafari et al. [36]. The authors investigated the antibacterial potential of D. salina extracts against Streptococcus mutans strain PTCC 1683, a Gram-positive bacterium causal agent of dental caries, showing that an inhibitory effect in serial dilution concentrations between 0.75 to $25 \mathrm{mg} \mathrm{mL}^{-1}$ started at $6.25 \mathrm{mg} \mathrm{mL}^{-1}$. Despite $D$. salina being known for its antimicrobial properties, as reported in the literature [22,37], based on our current knowledge, there are no data about its effectiveness against bacterial plant pathogens.

In addition to the preliminary screening, in vivo trials were performed in order to confirm the promising antibacterial activity shown by the hexane extracts of $D$. salina against two important phytopatogenic bacteria, i.e., P. syringae and P. carotovorum. The present study showed, for the first time, that treatments with $D$. salina extracts significantly reduced the incidence of bacterial speck spots and bacterial soft rot diseases.

Certainly, in natural conditions without artificial inoculation, it might be hypothesized that a better effectiveness of $D$. salina microalgae extracts to control these two important plant diseases could be achieved.

On the basis of $D$. salina chemical composition it might be presumed that the antibacterial activity was related to $\beta$-carotene as a major component. This hypothesis seems to be supported by comparing the antimicrobial activities of $D$. salina extracts with that observed using the chemical standard of $\beta$-carotene.

The standard $\beta$-carotene showed significant antibacterial activity against $P$. syringae, $P$. carotovorum, and B. subtilis and not statistically significant differences were in comparison to the activity of the D. salina hexane extracts. Excellent results in antibacterial activity of carotenoids were reported in several independent studies carried out on microalgae and in particular on D. salina biomass [20,21,38-42]. In particular, Bhagavathy et al. [43] associated the antimicrobial effects of extracts from green algae, Chlorococcum humicola, to major coloring pigment ( $\beta$-carotene).

Although further efforts are needed to precisely identify the molecules contained in $D$. salina which manifest antimicrobial properties, the presented results highlight that the comparison between antimicrobial activity of $D$. salina extracts with those of the beta-carotene standard would demonstrate that the $\beta$-carotene could be the main antibacterial compound in the extract against the tested pathogenic microorganisms.

\section{Materials and Methods}

\subsection{Extraction and Chemical Characterization of D. salina Microalgae}

Dunaliella salina biomass was supplied as dry powder with a particle size lower than $50 \mu \mathrm{m}$ by Algalimento, a Spanish company that cultivate microalgae for commercial applications in food and pharmaceutical industries. The biomass was stored at $-20{ }^{\circ} \mathrm{C}$ in a plastic bag under vacuum to avoid degradation until characterization and extraction.

Before the chemical extraction, in order to increase the yield, the dry microalgae biomass was added with diatomaceous earth and pretreated mechanically at $500 \mathrm{rpm}$ for $5 \mathrm{~min}$ by ball mill of Retsch MM400 ${ }^{\circledR}$ (Fisher Scientific, UK) [44-47]. Subsequently, pressurized fluid extraction (PFE) was carried out by a Dionex ASE ${ }^{\circledR} 200$ extractor (Salt Lake City, UT, USA). Stainless-steel extraction cells with a volume of $11 \mathrm{~mL}$ were filled in consecutive layers with a cellulose filter (20 $\mu \mathrm{m}$ pore size), a $2-3 \mathrm{~cm}^{3}$ 
layer of inert material (diatomaceous earth), $2.0 \mathrm{~g}$ pretreated microalgae biomass, and an additional layer of inert material. Extraction cells and collection vials were loaded into the automated carousel and the pre-heating time of the cells was fixed at $5 \mathrm{~min}$. Extracts were collected into $40 \mathrm{~mL}$ amber glass vials by flushing the system with $6.6 \mathrm{~mL}$ of fresh solvent after each extraction tests. At the end of each extraction, the system was purged for $1 \mathrm{~min}$ with nitrogen. Solvents with different polarity were used for the extraction of antimicrobial compounds from D. salina. Chloroform:Methanol (1:1), ethanol, and hexane were used as extraction solvents at $50{ }^{\circ} \mathrm{C}$ and $100 \mathrm{bar}$, and the extraction was carried for 2 cycles; each one lasted $10 \mathrm{~min}$.

The microalgae biomass of D. salina and its extracts were characterized in terms of humidity, ash, total dietary fiber (TDFs), carbohydrates, proteins, fatty acids, and carotenoids following standard methods as earlier reported [44]. In particular, the total content of carotenoids was quantified using an Agilent 1290 Infinity II uHPLC equipped with a diode array detector (DAD) and an Agilent Zorbax Eclipse plus C18 column $1.8 \mu \mathrm{m}$ column. For detection and quantification of individual species, such as lutein, beta-carotene, and astaxanthin, wavelengths of $444 \mathrm{~nm}, 450 \mathrm{~nm}, 478 \mathrm{~nm}$, respectively, were used [47]. The chromatographic analyses were ran as indicated in the standard method UNI EN 12823-2 [48] and in the paper by Ruen-ngam et al. [49].

\subsection{In Vitro Antimicrobial}

The phytopathogenic bacterial strains P. syringae pv. tomato EPS3 strain and B. subtilis strain ET-1 were provided by the laboratory of the ENEA Research Centre, Italy, while P. carotovorum subsp. carotovorum strain DSM30168 was supplied by by DSMZ_-German Collection of Microorganisms and Cell Cultures, Germany. The bacterial strains were used for antimicrobial trials in vitro. and The EPS3 was cultured on Medium 54 (glucose $20.0 \mathrm{~g} \mathrm{~L}^{-1}$, yeast extract $10.0 \mathrm{~g} \mathrm{~L}^{-1}, \mathrm{CaCO}_{3} 20.0 \mathrm{~g} \mathrm{~L}^{-1}$, agar $17.0 \mathrm{~g} \mathrm{~L}^{-1}$ ) at $26^{\circ} \mathrm{C}$, while strains DSM30168 and ET-1 on nutrient agar (NA; Sigma-Aldrich, USA) at $30{ }^{\circ} \mathrm{C}$.

\subsubsection{Agar Disc Diffusion Method}

The agar disc diffusion method was carried out to evaluate the antimicrobial activity of $D$. salina extracts. The extracts obtained by different solvents were dried at $40{ }^{\circ} \mathrm{C}$ by a speed dry vacuum concentrator. The dry weight was determined for each sample after drying and concentration steps. On the basis of their solubility, the extracts were subsequently dissolved in different aliquots of sterile dimethyl-sulfoxide (DMSO).

Briefly, an aliquot of different extracts $(10 \mu \mathrm{L})$ was loaded on sterile filter paper discs $(6 \mathrm{~mm}$ in diameter, Whatman no. 03) that were placed on NA and Medium 54 plates inoculated with a bacterial suspension containing $10^{5}$ cells $\mathrm{mL}^{-1}$. For negative, solvent, and positive controls, paper discs containing $10 \mu \mathrm{L}$ of sterile water, DMSO, and one standard antibiotic (ciprofloxacin) were used, respectively. All plates were incubated at $26^{\circ} \mathrm{C}$ for $5-7$ days. After the incubation time, the diameter of the inhibition zones around the discs were measured using a digital caliber. For all tested bacteria, three replicates were performed.

\subsubsection{Minimum Inhibitory Concentration (MIC)}

A broth dilution method was used for determination of the minimum inhibitory concentrations (MICs) of D. salina extracts. The dried extracts obtained after evaporating at $40{ }^{\circ} \mathrm{C}$ by a speed dry vacuum concentrator were subsequently dissolved in DMSO in order to obtain the following concentration: $16.25,32.5,75.0,150.0$, and $400.0 \mathrm{mg} \mathrm{mL}^{-1}$. Each sterile tube $(1.5 \mathrm{~mL})$ was prepared by dispensing into $193 \mu \mathrm{L}$ of liquid medium, $2 \mu \mathrm{L}$ of the different extracts at the two concentrations and $5 \mu \mathrm{L}$ of the bacteria suspensions containing $1 \times 10^{5}$ cells $\mathrm{mL}^{-1}$. For each tube, the final volume was of $200 \mu \mathrm{L}$. Liquid medium with DMSO at $1 \%$ was used as a negative control. All tubes were incubated at a temperature of $26{ }^{\circ} \mathrm{C}$ in a shaker incubator (Thermomixer comfort by Eppendorf). After an incubation period of 2 days, the antibacterial activity was detected by counting the viable 
cells. For this purpose, $50 \mu \mathrm{L}$ of cell culture from the different tube were decimally diluted and spread on agar plates. After $48 \mathrm{~h}$ of incubation at $26^{\circ} \mathrm{C}$, the number of colonies was counted and compared with the number of viable cells present in the culture broth at the time of inoculation. For each extract, the lowest concentration that clearly prevented the microorganism growth was designated as MIC. Each test was replied three times.

\subsection{In Vivo Antimicrobial Assay}

On the basis of in vitro assay, a volume of $D$. salina hexane extract $(100 \mathrm{~mL})$ was dried at $35^{\circ} \mathrm{C}$ using a rotary evaporator instrument (Steroglass, Perugia, Italy) and after dry weight was quantified using an analytical balance (KERN \& SOHN GmbH, Germany). The dried extracts were dissolved in absolute ethanol to a final concentration of $100 \mathrm{mg} \mathrm{mL}^{-1}$ and subsequently diluted with sterilized distilled water up to 10 and $5 \mathrm{~g} \mathrm{~L}^{-1}$.

\subsubsection{Application of D. salina Extracts to Bacterial Speck Spot caused by P. syringae}

The effect of $D$. salina extracts was evaluated in vivo on tomato plants. Young plants of Lycopersicon esculentum (L.) cv. Tomito F1 (ISI Sementi SPA, Italy), a commercial cultivar without resistance genes to Pst, was used for in vivo trials. The plants were transplanted on plastic pots $(28 \mathrm{~cm} \times 40 \mathrm{~cm})$ containing universal substrate (Florarura) and grown in an experimental greenhouse located at ENEA Research Center (Rotondella, Matera) Italy.

The leaves of tomato plants that were 1 month old were gently touched before the treatments and inoculation, in order to produce superficial wounds similar to those caused by transplanting and cultural practices. Preventive treatments were done by spraying D. salina extracts $\left(10 \mathrm{mg} \mathrm{mL}^{-1}\right) \mathrm{through}^{\mathrm{g}}$ a glass TLC sprayer on the adaxial and abaxial leaf surfaces until their surface became homogeneously wet. Solvent and positive controls have been prepared by spraying plants with an emulsifying solution of ethanol 10\% and distilled water, respectively. Healthy control plants were sprayed with physiological water only. After $6 \mathrm{~h}$, bacterial suspension containing $10^{7}$ cells $\mathrm{mL}^{-1}$, previously prepared by centrifuging culture and suspending the cells in physiological water, was spray-inoculated on tomato plants $(0.5 \mathrm{~mL}$ for each plant). During the experiments day and night temperature were set at $22{ }^{\circ} \mathrm{C}$ and $15^{\circ} \mathrm{C}$ while, the relative humidity was greater than $80 \%$ to support stomata opening. Tomato plants were monitored for 15 days and three replicates were carried out such as each test has been repeated three times. Disease incidence (DI) and disease severity (DS) were evaluated recording the symptoms on 150-200 leaves per treatment. Disease incidence (DI) is the percentage of infected leaves that was determined by the following formula:

$$
\mathrm{DI} \%=(\mathrm{IL} / \mathrm{L}) \times 100
$$

where IL is the number of infected leaves and $\mathrm{L}$ is the number of recorded leaves.

DS was analyzed according to Gullino et al. [50]. In particular, a visual scale from 0 to 5 based on disease symptoms was adopted to score the disease leaves as follows: $0=$ no symptom; $1=$ up to $5 \%$ infected leaf area; $2=6 \%$ to $10 \%$ infected leaf area; $3=11 \%$ to $25 \%$ infected leaf area; $4=26 \%$ to $50 \%$ infected leaf area; $5=51 \%$ to $100 \%$ infected leaf area. It describes the damage caused by the diseases on plants leaves and was calculated by the following formula (2):

$$
\mathrm{DS}=\sum\left(\mathrm{n}^{\circ} \text { leaves }{ }^{*} \mathrm{X}_{0-5}\right) /(\text { total of leaves recorded })
$$

with $\mathrm{X}_{0-5}=(\mathrm{X} 0=0 ; \mathrm{X} 1=3 \% ; \mathrm{X} 2=8 \% ; \mathrm{X} 3=18 \% ; \mathrm{X} 4=38 \% ; \mathrm{X} 5=75.5 \%) ; \mathrm{n}$ leaves: number of leaves for each class.

A randomized complete block design was applied with three replicates thus each test were repeated three times. In each replicate, three treatments (D. salina extracts, positive control and solvent control) were considered. For each set one plastic pot with 8 plants was used. The experiments were repeated twice with a total of 96 tomato plants for each experiment ( 8 plants $\times 4$ treatments $\times 3$ replicates). 


\subsubsection{Application of D. salina Extracts to Control Bacterial Soft Rot caused by P. carotovorum}

The effectiveness of D. salina extracts on bacterial disease caused by P. carotovorum subsp. carotovorum was investigated with two in vivo trials on fresh tomatoes and zucchini fruits.

Fresh tomato (Lycopersicon esculentum cv. Pixel) fruits were selected uniform in size and color, and without wounds. The fruits were washed with tap water and the surface was dipping in $0.1 \%$ sodium hypochlorite solution for $10 \mathrm{~min}$, rinsed sterile twice by using distilled water, and dried in ambient air. Four uniform wounds ( $2 \mathrm{~mm}$ deep and $0.5 \mathrm{~mm}$ wide) were made in three equidistant points on one side of each fruit. Wounded fruits were immersed for $1 \mathrm{~min}$ in D. salina extracts formulations at concentration of 5 and $10 \mathrm{~g} \mathrm{~L}^{-1}$. Positive and solvent controls fruits were treated by dipping in distilled water and in $10 \%$ ethanol, respectively. Each wound was inoculated with an aliquot $(10 \mu \mathrm{L})$ of P. carotovorum subsp. carotovorum $\left(10^{6}\right.$ cells $\left.\mathrm{mL}^{-1}\right)$ in physiological water. Wounded fruits that were used as healthy control, were not inoculated and were treated only with physiological water.

Zucchini fruits (Cucurbita pepo L. cv Afrodite) wounded making a cut ( $3 \mathrm{~mm}$ deep, $10 \mathrm{~mm}$ long) in three equidistant points along a longitudinal line with a sterile scalpel blade. Each wound was impregnated with the two different concentrations of $D$. salina extracts $(500 \mu \mathrm{L})$. For positive and solvent controls, wounds were impregnated with $500 \mu \mathrm{L}$ of distilled water and $10 \%$ ethanol, respectively. Each wound was inoculated with a $10 \mu \mathrm{L}$ aliquot containing $10^{6}$ cells $\mathrm{mL}^{-1}$ of P. carotovorum subsp. carotovorum. Wounded fruits treated only with physiological water were used as healthy control.

Tomatoes and zucchini fruits were placed in a plastic container and incubated at $24{ }^{\circ} \mathrm{C}$ and $80-85 \%$ relative humidity (RH). Disease incidence was assessed by recording the number of infected wounds at 48 and $96 \mathrm{~h}$ after inoculation. In tomatoes, infected and diseased wounds showed rot signs at the inoculation points while, in zucchini a transversal section was made at the inoculation points to detect rot signs. The percentage of DI was calculated using formula (3):

$$
\mathrm{DI} \%=(\mathrm{IW} / \mathrm{W}) \times 100
$$

where, $\mathrm{W}$ is the number of wounds and IW is the number of infected wounds.

A randomized complete design was used for three replicates. For each replicate, four treatments (D. salina extracts at concentration of 10 and $5 \mathrm{mg} \mathrm{mL}^{-1}$, positive control and solvent control) were considered. Two sets of three replicates: one with 10 tomatoes per replicate and another with 4 zucchini per replicate, were prepared for each treatment (4 treatments $\times 3$ replicates $\times 10$ or 4 fruits for a total of 120 tomatoes and 48 zucchinis for each experiment). The experiments were repeated twice.

\section{4. $\beta$-carotene Concentration and Antibacterial Activity}

The antibacterial activity of $D$. salina extracts against $P$. syringae, $P$. carotovorum and B. subtilis at concentration of $100 \mathrm{mg} \mathrm{mL}^{-1}$ was compared with a $\beta$-carotene chemical standard (Sigma Chemical) at concentration of 10, and $5 \mathrm{mg} \mathrm{mL}^{-1}$ through the Agar Disc Diffusion method. Briefly, the cells of different bacteria species were removed with sterile loop from 4 days old single colonies and dissolved into $1 \mathrm{~mL}$ of sterile distilled water in order to obtain a final concentration of $1 \times 10^{6}$ cells $\mathrm{mL}^{-1}$. An aliquot of cell suspension $(100 \mu \mathrm{L})$ was uniformly spread on the surface of plates $(90 \mathrm{~mm})$ containing approximately $20 \mathrm{~mL}$ of NA medium. For each bacterial species, a volume of $10 \mu \mathrm{L}$ of three different extracts of $D$. salina and $\beta$-carotene were loaded on paper discs placed on NA plates that were incubated at $25^{\circ} \mathrm{C}$ for $7-10$ days. After the incubation time, the diameter inhibition zones around the discs were measured using a digital caliber. The assay was repeated three times.

\subsection{Statistical Analyses}

The effects of $D$. salina extracts (independent variables) on the two bacterial diseases (dependent variables) were examined using Statistical Analysis System software (SAS Institute Inc., Cary, NC, USA). Prior to analysis, the data were verified for homogeneity of variance and for normal distribution. In each in vivo trial, the data of the two repeated experiments were pooled and analyzed as a completely 
randomized design. Means were separated by Tukey's HSD test when the analysis of variance showed statistical significance $(\alpha=0.05)$.

\section{Conclusions}

In this study, the extracts obtained from the microalgae $D$. salina by using pressurized fluid extraction technology and using solvents with different polarities show antibacterial activity. The best performances in vitro have been found for hexane extracts. On young tomato plants, D. salina extracts) reduced up to $65.7 \%$ and $77.0 \%$ in incidence and severity, respectively, of bacterial speck spot disease. Similarly, it was observed a strong reduction of soft rot symptoms on tomato and zucchini fruits artificially inoculated and treated with two different concentrations of extracts. In particular, treated tomatoes and zucchini showed a disease incidence of $5.3 \%$ and $12.6 \%$, respectively, while at same time on the corresponding positive controls, the disease incidence achieved $80.6 \%$ for tomato and $100 \%$ for zucchini.

Author Contributions: A.A. and M.T. designed and developed the experimental set-up; A.M. and R.B. conceived the experimental tests; A.A., R.M. and M.T. performed the experimental tests; A.M., E.H. and D.M. supervised the project; A.F., P.C., T.M. collected and analyzed the data; T.M. and A.M. wrote the paper; A.M. was responsible for the overall direction, planning, and integration among different research units. All authors have read and agree to the published version of the manuscript.

Funding: This paper has received funding from the Bio Based Industries Joint Undertaking under the European Union's Horizon 2020 research and innovation program under grant agreement No. 745695 (VALUEMAG).

Conflicts of Interest: The authors declare no conflict of interest.

\section{References}

1. Compant, S.; Samad, A.; Faist, H.; Sessitsch, A. A review on the plant microbiome: Ecology, functions, and emerging trends in microbial application. J. Adv. Res. 2019, 19, 29-37. [CrossRef]

2. Savary, S.; Willocquet, L.; Pethybridge, S.J.; Esker, P.; McRoberts, N.; Nelson, A. The global burden of pathogens and pests on major food crops. Nat. Ecol. Evol. 2019, 3, 430-439. [CrossRef] [PubMed]

3. Fitt, B.D.; McCartney, H.A.; West, J.S. Dispersal of Foliar Plant Pathogens: Mechanisms, Gradients and Spatial Patterns; Jones, D.G., Ed.; The Epidemiology of Plant Diseases; Springer: Dordrecht, the Netherlands, 2006; pp. 159-192. [CrossRef]

4. Levetin, E. Aerobiology of Agricultural Pathogens. In Manual of Environmental Microbiology; Yates, M.V., Nakatsu, C.H., Miller, R.V., Pillai, S.D., Eds.; ASM Press: Washington, DC, USA, 2015. [CrossRef]

5. Sosnowski, M.R.; Fletcher, J.D.; Daly, A.M.; Rodoni, B.C.; Viljanen-Rollinson, S.L.H. Techniques for the treatment, removal and disposal of host material during programmes for plant pathogen eradication. Plant Pathol. 2009, 58, 621-635. [CrossRef]

6. Singh, D.; Sharma, R.R. Postharvest diseases of fruits and vegetables and their management. In Postharvest Disinfection of Fruits and Vegetables; Academic Press: London, UK, 2018; pp. 1-52. [CrossRef]

7. Ganeshan, S.; Neetoo, H. Pre-harvest Microbial Contamination of Tomato and Pepper Plants: Understanding the Pre-harvest Contamination Pathways of Mature Tomato and Bell Pepper Plants Using Bacterial Pathogen Surrogates. Adv. Crop Sci. Tech. 2015, 4, 1-8. [CrossRef]

8. Mansfield, J.; Genin, S.; Magori, S.; Citovsky, V.; Sriariyanum, M.; Ronald, P.; Dow, M.; Verdier, V.; Beer, S.V.; Machado, M.A.; et al. Top 10 plant pathogenic bacteria in molecular plant pathology. Mol. Plant Pathol. 2012, 13, 614-629. [CrossRef]

9. Bhat, K.; Masood, N.; Bhat, N.; Ashraf, B.M.; Razvi, S.; Mi, M.; Akhtar, N.; Habib, M.B. Current status of post harvest soft rot in vegetables: A review. Asian J. Plant Sci. 2010, 9, 200-208. [CrossRef]

10. Pérombelon, M.C.M. Potato diseases caused by soft rot erwinia: An overview of pathogenesis. Plant Pathol. 2002, 51, 1-12. [CrossRef]

11. Gašić, K.; Gavrilović, V.; Dolovac, N.; Trkulja, N.; Živković, S.; Ristić, D.; Obradović, A. Pectobacterium carotovorum subsp. carotovorum: The causal agent of broccoli soft rot in Serbia. Pestic. Phytomed. 2014, 29, 249-255. [CrossRef] 
12. Xin, X.; Kvitko, B.; He, S. Pseudomonas syringae: What it takes to be a pathogen. Nat. Rev. Microbiol 2018, 16, 316-328. [CrossRef]

13. Eastburn, D.M.; McElrone, A.J.; Bilgin, D.D. Influence of atmospheric and climatic change on plant-pathogen interactions. Plant Pathol. 2011, 60, 54-69. [CrossRef]

14. Manyi-Loh, C.; Mamphweli, S.; Meyer, E.; Okoh, A. Antibiotic use in agriculture and its consequential resistance in environmental sources: Potential public health implications. Molecules 2018, 23, 795. [CrossRef] [PubMed]

15. Mahamoud Ahmed, A.; Lyautey, E.; Bonnineau, C.; Dabrin, A.; Pesce, S. Environmental concentrations of copper, alone or in mixture with arsenic, can impact river sediment microbial community structure and functions. Front Microbiol. 2018, 9, 1852. [CrossRef] [PubMed]

16. Lamichhane, J.R.; Osdaghi, E.; Behlau, F.; Köhl, J.; Jones, J.B.; Aubertot, J. Thirteen decades of antimicrobial copper compounds applied in agriculture. A review. Agron. Sustain. Dev. 2018, 38, 28. [CrossRef]

17. Sargent, S.A.; Ritenour, M.A.; Brecht, J.K. Handling, Cooling and Sanitation Techniques for Maintaining Postharvest Quality; University of Florida Cooperative Extension Service, Institute of Food and Agriculturesciences: Gainesville, FL, USA, 2000; pp. 1-17.

18. Ördög, V.; Stirk, W.A.; Lenobel, R.; Bancířová, M.; Strnad, M.; van Staden, J.; Szigeti, J.; Németh, L. Screening microalgae for some potentially useful agricultural and pharmaceutical secondary metabolites. J. Appl. Phycol. 2004, 16, 309-314. [CrossRef]

19. Foteini, K.; Pavlos, M.; Maroudio, K.; Pascal, D. Antibacterial activity in microalgae cultures. Aquac. Res. 2011, 43, 1520-1527. [CrossRef]

20. Aiyar, P.; Schaeme, D.; García-Altares, M.; Carrasco Flores, D.; Dathe, H.; Hertweck, C.; Sasso, S.; Mittag, M. Antagonistic bacteria disrupt calcium homeostasis and immobilize algal cells. Nat. Commun. 2017, 8, 1756. [CrossRef]

21. Metzger, P.; Rager, M.-N.; Largeau, C. Botryolins A and B, two tetramethylsqualene triethers from the green microalga. Botryococcus Braunii Phytochem. 2002, 59, 839-843. [CrossRef]

22. Mhadhebi, L.; Chaieb, K.; Bouraoui, A. Evaluation of antimicrobial activity of organic fractions of six marine algae from Tunisian Mediterranean coasts. Int. J. Pharm. Pharm. Sci. 2012, 4, 534-537.

23. Bergmann, W.; Feeney, R.J. Contributors to the study of marine products. XXXII. The nucleosides of sponges. I.1. J. Org. Chem. 1951, 16, 981-987. [CrossRef]

24. Bergmann, W.; Feeney, R.J. The isolation of a new thymine pentoside from sponges. J. Am. Chem. Soc. 1950, 72, 2809-2810. [CrossRef]

25. Baker, J.T. Seaweeds in pharmaceutical studies and applications. In Eleventh International Seaweed Symposium; Bird, C.J., Ragan, M.A., Eds.; Springer: Dordrecht, The Netherlands, 1984; pp. 29-40.

26. Iglesias, M.J.; Soengas, R.; Probert, I.; Guilloud, E.; Gourvil, P.; Mehiri, M.; López, Y.; Cepas, V.; Gutiérrez-del-Río, I.; Redondo-Blanco, S.; et al. NMR characterization and evaluation of antibacterial and antiobiofilm activity of organic extracts from stationary phase batch cultures of five marine microalgae (Dunaliella sp., D. salina, Chaetoceros calcitrans, C. gracilis and Tisochrysis lutea). Phytochemistry 2019, 164, 192-205. [CrossRef] [PubMed]

27. Amal Maadane, A.; Merghoub, N.; El Mernissi, N.; Ainane, T.; Amzazi, S. Antimicrobial activity of marine microalgae isolated from Moroccan coastlines. J. Microbiol. Biotechnol. Food Sci. 2017, 6, 1257-1260. [CrossRef]

28. Tao, N.; Gao, Y.; Liu, Y.; Ge, F. Carotenoids from the peel of Shatian pummelo (Citrus grandis Osbeck) and its antimicrobial activity. Am. Eurasian J. Agric. Environ. Sci. 2010, 7, 110-115.

29. Ravikumar, S.; Uma, G.; Gokulakrishnan, R. Antibacterial property of halobacterial carotenoids against human bacterial pathogens. J. Sci. Ind. Res. 2016, 75, 253-257.

30. Herrero, M.; Ibanez, E.; Cifuentes, A.; Reglero, G.; Santoyo, S. Dunaliella salina microalga pressurized liquid extracts as potential antimicrobials. J. Food Prot. 2006, 69, 2471-2477. [CrossRef] [PubMed]

31. Srinivasakumar, K.; Rajashekhar, M. In vitro studies on bactericidal activity and sensitivity pattern of isolated marine microalgae against selective human bacterial pathogens. Indian J. Sci. Technol. 2009, 2, 16-23. [CrossRef]

32. Widowati, I.; Zainuri, M.; Kusumaningrum, H.P.; Maesaroh, Y.; Hardivillier, Y.; Leignel, V.; Bourgougnon, N.; Mouget, J. Identification of agents causing vibriosis in Litopenaeus vannamei shrimp culture in Kendal, Central Java, Indonesia and application of microalgae Dunaliella salina and Tetraselmis chui as bio-control agents against vibriosis. Aquac. Aquar. Conserv. Legis. 2018, 11, 101-107. 
33. Pane, G.; Cacciola, G.; Giacco, E.; Mariottini, G.L.; Coppo, E. Assessment of the antimicrobial activity of algae extracts on bacteria responsible of external otitis. Mar. Drugs 2015, 13, 6440-6452. [CrossRef]

34. Sheu, C.W.; Freese, E. Lipopolysaccharide layer protection of Gram-negative bacteria against inhibition by long-chain fatty acids. J. Bacteriol. 1973, 115, 869-875. [CrossRef]

35. Clelia, A.; Antonio, B.; Daniela, C.; Milena, S. Effectiveness of fatty acids and their monoglycerides against Gram-negative pathogens. Int. J. Food Sci. Technol. 2008, 44, 359-366. [CrossRef]

36. Jafari, S.; Mobasher, M.A.; Najafipour, S.; Ghasemi, Y.; Mohkam, M.; Ebrahimi, M.A.; Mobasher, N. Antibacterial potential of Chlorella vulgaris and Dunaliella salina extracts against Streptococcus mutans. Jundishapur J. Nat. Pharm. Prod. 2018, 13, e13226. [CrossRef]

37. Mendola, J.A.; Santoyo, S.; Cifuentes, A.; Reglero, G.; Ibáñez, E.; Señoráns, F.J. Antimicrobial activity of suband supercritical CO2 extracts of the green alga Dunaliella salina. J. Food Prot. 2008, 71, 2138-2143. [CrossRef] [PubMed]

38. Cakmak, Y.S.; Kaya, M.; Asan-Ozusaglam, M. Biochemical composition and bioactivity screening of various extracts from Dunaliella salina, a green microalga. EXCLI J. 2014, 13, 679-690. [PubMed]

39. Manimala, M.R.A.; Murugesan, R. In vitro antioxidant and antimicrobial activity of carotenoid pigment extracted from Sporobolomyces sp. isolated from natural source. J. Appl. Nat. Sci. 2014, 6, 649-653. [CrossRef]

40. Falaise, C.; François, C.; Travers, M.-A.; Morga, B.; Haure, J.; Tremblay, R.; Turcotte, F.; Pasetto, P.; Gastineau, R.; Hardivillier, Y. Antimicrobial compounds from eukaryotic microalgae against human pathogens and diseases in aquaculture. Mar. Drugs. 2016, 14, 159. [CrossRef]

41. Jena, J.; Subudhi, E. Microalgae: An untapped resource for natural antimicrobials. In The Role of Microalgae in Wastewater Treatment; Springer: Singapore, 2019; pp. 99-114. [CrossRef]

42. Kirti, K.; Amita, S.; Priti, S.; Mukesh Kumar, A.; Jyoti, A. Colorful World of Microbes: Carotenoids and their applications. Adv. Biol. 2014, 1-13. [CrossRef]

43. Bhagavathy, S.; Sumathi, P.; Jancy Sherene Bell, I. Green algae Chlorococcum humicola- a new source of bioactive compounds with antimicrobial activity. Asian Pac. J. Trop. Biomed. 2011, 1, 1-7. [CrossRef]

44. Molino, A.; Iovine, A.; Casella, P.; Mehariya, S.; Chianese, S.; Cerbone, A.; Rimauro, J.; Musmarra, D. Microalgae characterization for consolidated and new application in human food, animal feed and nutraceuticals. Int. J. Environ. Res. Public Health 2018, 15, 2436. [CrossRef]

45. Di Sanzo, G.; Mehariya, S.; Martino, M.; Larocca, V.; Casella, P.; Chianese, S.; Musmarra, D.; Balducchi, R.; Molino, A. supercritical carbon dioxide extraction of astaxanthin, lutein, and fatty acids from Haematococcus pluvialis microalgae. Mar. Drugs. 2018, 16, 334. [CrossRef]

46. Molino, A.; Rimauro, J.; Casella, P.; Cerbone, A.; Larocca, V.; Chianese, S.; Karatza, D.; Mehariya, S.; Ferraro, A.; Hristoforou, E.; et al. Extraction of astaxanthin from microalga Haematococcus pluvialis in red phase by using generally recognized as safe solvents and accelerated extraction. J. Biotechnol. 2018, 283, 51-61. [CrossRef]

47. Molino, A.; Mehariya, S.; Iovine, A.; Larocca, V.; Di Sanzo, G.; Martino, M.; Casella, P.; Chianese, S.; Musmarra, D. Extraction of astaxanthin and lutein from microalga Haematococcus pluvialis in the red phase using CO2 supercritical fluid extraction technology with ethanol as co-solvent. Mar. Drugs. 2018, 16, 432. [CrossRef] [PubMed]

48. UNI EN 12823-2:2000. Foodstuffs Determination of Vitamin a by High Performance Liquid Chromatography Measurement of $\beta$-carotene. Available online: http://store.uni.com/catalogo/index.php/uni-en-12823-2-2000. html?_store=it\&_from_store=en (accessed on 13 August 2018).

49. Ruen-ngam, D.; Shotipruk, A.; Pavasant, P. Comparison of extraction methods for recovery of astaxanthin from Haematococcus pluvialis. Sep. Sci. Technol. 2011, 46, 64-70. [CrossRef]

50. Gullino, M.L.; Gilardi, G.; Sanna, M.; Garibaldi, A. Epidemiology of Pseudomonas syringae pv. syringae on tomato. Phytoparasitica 2009, 37, 461. [CrossRef]

(C) 2020 by the authors. Licensee MDPI, Basel, Switzerland. This article is an open access article distributed under the terms and conditions of the Creative Commons Attribution (CC BY) license (http://creativecommons.org/licenses/by/4.0/). 